LRH: WETLANDS, Vol. 22, No. 3, 2002

RRH: Barbiéro et al., GEOCHEMISTRY OF WATER AND GROUND WATER IN

THE PANTANAL

\title{
GEOCHEMISTRY OF WATER AND GROUND WATER IN THE NHECOLÂNDIA, PANTANAL OF MATO GROSSO, BRAZIL: VARIABILITY AND ASSOCIATED PROCESSES
}

\author{
Laurent Barbiéro $^{1}$, José P. de Queiroz Neto ${ }^{2}$, Gilles Ciornei ${ }^{3}$ \\ Arnaldo Y. Sakamoto ${ }^{4}$, Benjamin Capellari ${ }^{2}$, Erminio Fernandes ${ }^{2}$, and Vincent Valles ${ }^{5}$ \\ ${ }^{1}$ IRD-CEFIRSE \\ Indian Institute of Science \\ Department of Metallurgy \\ 560012 Bangalore, India \\ e-mail: barbiero@lmtg.obs-mip.fr \\ ${ }^{2}$ Departamento de Geografia \\ Universidade de São Paulo \\ C.P. 8105 \\ Cep 05508-900, São Paulo, Brazil \\ ${ }^{3}$ IRD \\ Centre de Hann \\ B.P. 1386, Dakar, Senegal \\ ${ }^{4}$ UFMS - Campus de Tres Lagoas \\ Av. Ranulfo Marques Leal 3484 \\ Cep 79600-000, Tres Lagoas-MS, Brazil \\ ${ }^{5}$ Laboratoire Chimie et Environnement, Case 29 \\ Université de Provence (Aix-Marseille I) \\ 3 Place Victor Hugo \\ 13331 Marseille Cedex 03, France
}

Abstract: A distinctive feature of the Nhecolândia, a sub-region of the Pantanal wetland in Brazil, is the presence of both saline and freshwater lakes. Saline lakes used to be attributed to a past arid phase during the Pleistocene. However, recent studies have shown that saline and fresh water lakes are linked by a continuous water table, indicating that saline water could come from a contemporary concentration process. This concentration process could also be responsible for the large chemical variability of the waters observed in the area. A regional water sampling has been conducted in surface and sub-surface water and the water table, and the results of the geochemical and statistical analysis are presented. Based on sodium contents, the concentration shows a 1: 4443 ratio. All the samples belong to the same chemical family and evolve in a sodic alkaline manner. Calcite or magnesian calcite precipitates very early in the process of concentration, probably followed by the precipitation of magnesian silicates. The most concentrated solutions remain under-saturated with respect to the sodium carbonate salt, even if this equilibrium is likely reached around the saline lakes. Apparently, significant amounts of sulfate and chloride are lost simultaneously from the solutions, and this cannot be explained solely by evaporative concentration. This could be 
attributed to the sorption on reduced minerals in a green sub-surface horizon in the "cordilhieira" areas. In the saline lakes, low potassium, phosphate, magnesium, and sulfate are attributed to algal blooms. Under the influence of evaporation, the concentration of solutions and associated chemical precipitations are identified as the main factors responsible for the geochemical variability in this environment (about $92 \%$ of the variance). Therefore, the saline lakes of Nhecolândia have to be managed as landscape units in equilibrium with the present water flows and not inherited from a past arid phase. In order to elaborate hydrochemical tracers for a quantitative estimation of water flows, three points have to be investigated more precisely: (1) the quantification of magnesium involved in the Mg-calcite precipitation; (2) the identification of the precise stoichiometry of the Mg-silicate; and (3) the verification of the loss of chloride and sulfate by sorption onto labile iron minerals.

Key Words: concentration, alkalinity, calcite, saline lakes, Nhecolândia, Pantanal, Brazil

\section{INTRODUCTION}

The presence of salt is frequently used for reconstructing paleoenvironments. The reconstruction is based on various features, extending from the morphology of saline areas to the chemical profile of salinity. Due to their high solubility, salts generally indicate an arid phase in a present or past climate but are quickly eliminated when the climate turns wet again. In the Nhecolândia, a sub-region of the Bazilian Pantanal wetland (Figure 1) located between the Taquari and the Negro rivers, there are many saline round lakes ("Salinas"), which are considered as characteristic of the area (Cunha 1943, Brum and Souza 1985, Mourão et al. 1988). Different hypotheses have been formulated to explain the origin of these salinas and their associated sandy banks (called "Cordilheiras"), and their genesis is still under debate. One hypothesis, which does not consider the presence of salts, involves the shifting of river courses. The regularly shaped lakes would then result from depressions surrounded by cut-off meander banks. Similarly, banks with short-cut meanders would turn into cordilheiras, as suggested by Wilhelmy (1958) and later corroborated by Ab'Saber (1988). Another hypothesis involves wind deflation in combination with high salinity of soils (Almeida and Lima 1956) and/or accumulation of sand-size particles as in the "Sebkha" dune type (Tricart 1982). Klammer (1982) conceded that it is only a partial explanation, since some areas have such paleodunes without the accompanying lakes. Moreover, no deposit features of these paleodunes have ever been identified in the soils (Colinvaux et al. 2000). Eiten (1983) attributed the lakes to a karstic or pseudo-karstic system. In all these studies, the presence of salts is attributed to an old phenomenon and, in particular, to the alternations of wet and arid phases during Pleistocene (Ab'Saber 1988), which have been questioned today (Colinvaux et al. 2000). Klammer (1982) even proposed the term "paleodesert" to explain the presence of salty terminal lakes.

In recent studies, Fernandes et al. (1999), Queiroz Neto et al. (1999), and Sakamoto et al. (1999) have shown the presence of a continuous water table between the saline and the nonsaline lakes, which are supplied yearly by fresh water during floods of the river Taquari. The non-saline lakes and rivers contain sodic/calcic/(sometimes potassic) and carbonate/chloride waters, whereas the saline lakes contain sodic-carbonate water. The salty lakes are always 0.5 to $3 \mathrm{~m}$ lower than the surrounding fresh water lakes and should be continually supplied through the saturation zone by diffusing sub-surface flow. This would imply, contrary to the previous hypotheses, that the salty lakes do not result from a past arid phase but from present day processes. 
The objectives of this paper are to verify whether the geochemical features of the salty lakes could result from the present-day concentration of the poorly mineralized waters and whether this concentration process could explain the large chemical variability observed in this region.

\section{MATERIALS AND METHODS}

Site

The Pantanal of Mato Grosso, near the geographic center of South America in Brazil, is known as the world's largest wetland (Alho et al. 1988). However, it is perhaps one of the most unknown regions of the globe, as scientific information is surprisingly scarce (cf. Por 1995). Its landscape comprises a variety of ecological sub-regions (Da Silva and Abdon 1998), including river corridors, gallery forests, perennial wetlands and lakes, seasonally flooded grasslands, and terrestrial forests. Put together, these natural features form a large and biologically diverse ecosystem (Gottgens et al. 1998).

Situated between $16^{\circ}$ and $20^{\circ} \mathrm{S}$ and $58^{\circ}$ and $50^{\circ} \mathrm{W}$, the total extent of the Pantanal is about $200,000 \mathrm{~km}^{2}$ (Por 1995) (Figure 1). The north, east, and south borders are clearly marked by the Brazilian highlands at an altitude of about $400 \mathrm{~m}$ (Chapada dos Parecis, Serra São Jeronimo, Chapada dos Guimarães, Serra do Maracajú, Serra do Bodoquena). There is an opening in the North, through which the Paraguay River flows southward. In the South, the Paraguay River crosses the narrows between the mountains in an area called "Fecho dos Morros," considered to be the limit of the upper Paraguay basin. The surrounding mountains are all Precambrian or Paleozoic. They are locally iron- and manganese-rich and also contain large areas of calcareous rocks. Quaternary sediments, alluvial products of the Paraguay River effluents (Klammer 1982) and tributaries, cover the plain.

The elevation of the alluvial plain ranges from 100 to $200 \mathrm{~m}$ above sea level, with a slight North-South and East-West gradient. This vast plain provides a gigantic natural flood control device for the storm waters resulting from torrential rainfall during the wet period. Each year, the heavy tropical rains cause the main tributaries supplying the Pantanal waters to overflow. With the flood, the depressions are inundated and form extensive lakes, which coalesce into larger waterbodies. During the dry season, the floodwaters recede, resulting in a complex mosaic of grasslands and forests dotted with countless lakes and marshes.

Nhecolândia is a sub-region of the Pantanal wetland directly influenced by the Taquari River in the West and the Negro River in the South (Figure 2); the system of round lakes (saline or non-saline) is particularly well-developed here. During the dry season, these lakes cover about $30 \%$ of the area. Among all the lakes of Nhecolândia, Morrison et al. (2000) identified 499 salty lakes, which make up about $1 \%$ of the total surface area.

The soil cover consists of sandy soils with small patches of clay and lime soils. High sodium contents are observed locally, particularly in the Southern Nhecolândia. The most frequent soil ("Plintossolos" according to the Brazilian classification) is characterized by a low organic matter content and the presence of a deep green horizon, hardening irreversibly after air drying (Sakamoto 1997).

The seasonal floods of Nhecolândia floodplain occur in three ways: (1) the overbank flow of the Taquari river across its natural levees, (2) a backwater effect caused by the flooding of the Paraguay and Negro rivers and (3) local rainfall on lands with gentle slopes where drainage to river courses is delayed (Hamilton 1999). The backwater effect caused by the Paraguay and Negro rivers can locally and temporarily reverse the flow of some tributaries (Hamilton et al. 1998). The local hydrologic regime is much more complex, and the ground-water flows 
connecting the many lakes of the Nhecolândia are not yet understood.

The Pantanal has a tropical semi-humid climate, classified as "Aw" type in the Köppens classification. The average air temperature is about $32^{\circ} \mathrm{C}$ in summer. The winter season is dry and cold, and frost can form during the occasional influx of polar air masses from the south (IBGE 1989). The mean annual temperature is $25^{\circ} \mathrm{C}$. The mean annual precipitation is 1000 $\mathrm{mm}$, and most rainfall occur between October and April (Alho et al. 1988). The annual evapotranspiration is about $1400 \mathrm{~mm}$, giving a hydrologic deficit of about $400 \mathrm{~mm}$.

The landscape is constituted by special features with typical regional denominations, which will be used throughout the article (Figure 3):

- The "lagoas" are temporary or permanent lakes of the most variable forms and dimensions. They can reach approximately two meter depths.

- The "salinas" are permanent salty lakes. There are generally 500 to $1000 \mathrm{~m}$ in diameter, 2 to $3 \mathrm{~m}$ deep (during the dry season), and most commonly, are well delimited and/or isolated by a stripe of dryland or "cordilheiras."

- The "cordilheiras" are narrow (200-300 m wide) and elongated sand hills (2 to $5 \mathrm{~m}$ high) covered by savanna vegetation (Cerrado).

- The "vazantes" are natural drainage channels flowing periodically from lagoas during the flooding periods. They can be several kilometers long and are generally 10 to $30 \mathrm{~m}$ wide.

- The "corixos" are small periodic watercourses with their own riverbeds that link adjacent lagoas during flood periods. Their dimensions are similar to those of the vazantes.

Sampling

Water samples were collected during the period 1994 to 1999 in lagoas and salinas (41 samples), rivers (5 samples), vazantes and corixos (7 samples), and piezometers located in cordilheiras (12 samples). Samples were taken in the Negro River, the Abobral River, and three sites of Nhecolândia : Fazenda São Miguel do Firme, Fazenda Nhumirim and Fazenda Berenice (Figure 2). All the waters from lagoas, salinas, and watercourses were collected at about $1 \mathrm{~m}$ from the shoreline and at about $0.2 \mathrm{~m}$ in depth. Around the piezometers that were sampled, the depths of the water ranged between 1 to $2 \mathrm{~m}$ near the salinas or lagoas and between 4 and $6 \mathrm{~m}$ in the middle of the cordilheiras. About two or three liters of solution were taken from the piezometers with a manual vacuum pump before sampling. Water was collected only once from each sampling site and preserved at a temperature of $4^{\circ} \mathrm{C}$ until analysis. All samples were stored in acid rinsed opaque polyethylene containers.

\section{Chemical Analyses}

All the analyses were performed in the laboratory at the Sao Paulo University, Brazil, as well as in IRD Dakar, Senegal. The $\mathrm{pH}$, electrical conductivity, and temperature were measured on non-filtered samples. The samples were then filtered with $0.45-\mu \mathrm{m}$ cellulose acetate filters, and the total alkalinity was determined by acid titration with $\mathrm{HCl}$ (Gran 1952). Silica content was measured by colorimetry (ammonium molybdate method, Charlot 1961). Total magnesium, sodium, calcium, and potassium concentrations were measured by atomic absorption spectrometry (PERKIN ELMER 2000, Fassel 1978). Chloride, sulfate, nitrate, and phosphate concentrations were analyzed by capillary electrophoresis (WATERS, Capillary Ion Analyzer).

Data Analyses and Activity Coefficient Calculations

The considerations on solution/mineral equilibria are based on the activity coefficients of the dissolved ions, which have not been measured but estimated from the analyses. The ion pair 
model "AQUA" (Valles and De Cockborne 1992) derived from "GYPSOL" (Valles and Bourgeat 1988) was used for these calculations. This model is not based on the Scatchard's extension of the Debye-Hückel's law (Scatchard 1936) but on a specific extension that takes into account the solvent/solute interactions under strong ionic strengths (Valles, pers. Comm.)

\section{Statistical Approach}

An analysis of the variance and standard deviation was performed using the "AQUA" model on the following bulk parameters: Carbonate Alkalinity, $\mathrm{K}^{+}, \mathrm{Na}^{+}, \mathrm{Ca}^{2+}, \mathrm{Mg}^{2+}, \mathrm{Cl}^{-}$, and $\mathrm{SO}_{4}{ }^{2-}$. A principal component analysis (PCA) was performed, based on the correlation matrix, in order to sort the data and chemical parameters according to the factors that might explain the variability in the chemical characteristics of the sampling.

\section{Concentration Diagrams}

Data from all the samples were treated together and are presented in the concentration diagrams, regardless of whether they represent surface waters or ground waters. The concentration diagrams were built using $\mathrm{Na}^{+}$as a conservative tracer to estimate the concentration factor. As a result, the concentration factor is underestimated if a Na-salt precipitates (for example halite: $\mathrm{NaCl}$; natron: $\mathrm{Na}_{2} \mathrm{CO}_{3} \cdot 10 \mathrm{H}_{2} \mathrm{O}$; trona: $\mathrm{Na}_{2} \mathrm{CO}_{3} \cdot \mathrm{NaHCO}_{3} \cdot 2 \mathrm{H}_{2} \mathrm{O}$ ). In the case of very mineralized waters, this hypothesis needs to be verified.

Residual Alkalinity, Definition, and Property

Alkalinity is the sum of the weak base concentrations multiplied by the number of protons each base can neutralize, minus the number of protons in the solution (Stumm and Morgan 1970). In most soils and natural waters, the alkalinity is generally due to carbonate species (i.e., carbonate alkalinity), neglecting $\mathrm{H}^{+}$and $\mathrm{OH}^{-}$concentrations, organic anions, complex ions of phosphorus, silica, aluminum, and boron (Vorob'yeva and Zamana 1984, Keller et al. 1987):

Carbonate alkalinity $=\left[\mathrm{HCO}_{3}{ }^{-}\right]+\left[\mathrm{CO}_{3}{ }^{2-}\right]$

where square brackets [ ] denote total concentration expressed in equivalent per liter $\left(\mathrm{eq} \mathrm{L}^{-1}\right)$.

The concept of residual carbonates derived originally from Eaton (1950) was later redefined in terms of "residual alkalinity" as the difference between carbonate alkalinity and calcium amounts in the solution (Hardie and Eugster 1970, Van Beek and Van Breemen 1973, Droubi et al. 1980). When evaporation concentrates a solution up to calcite precipitation, two cases may arise. 1) Calcium equivalent is greater than the carbonate alkalinity, in which case, calcium molality increases and alkalinity decreases. The solution then evolves in a saline manner. 2) Calcium equivalent is less than the carbonate alkalinity, causing the molalities to change in the opposite direction and the solution to evolve in an alkaline manner by concentration. After each mineral precipitation, changes are observed in the rate of concentration of the elements. When saturation with respect to a new mineral is reached, the concentration of certain elements can decrease, increase again, or simply fluctuate along the evaporation processes. This concept is used here in order to interpret the changes in the evolution of each element as waters become more saline.

\section{Simulation}

The evolution of major ions along the concentration gradient was simulated using the "AQUA" model. The simulation starts from a poorly mineralized solution to a 4000 times more concentrated one. In this calculation, the $\mathrm{CO}_{2}$ partial pressure was kept constant and equal to $10^{-3,5}$ atm, which is not $\mathrm{PCO}_{2}$ in the field but the average value of $\mathrm{PCO}_{2}$ when the $\mathrm{pH}$ was measured in the laboratory. The possible precipitation of calcite, magnesite, magnesian silicate (sepiolite), and amorphous silica were activated during the simulation. The results of 
the simulation are compared to the distribution of the observed data in the concentration diagrams.

\section{RESULTS}

The ionic strength of the solutions varied from $0.15910^{-3}$ to 0.376 (i.e., in a $1 / 2365$ ratio). The most diluted solution was sampled in a corixo, whereas the most concentrated one came from the piezometer S13 near the "Sao Miguel do Firme" salina. The descriptive statistics for each element are given in Table 1 . Sodium and carbonate alkalinity showed the largest standard deviation in the data set. According to the sodium content, the most mineralized solution is 4443 times more concentrated than the least mineralized one. The changes in ionic strength came together with changes in the chemical profile of the solutions as presented on the Piper and Schöeller diagrams (Figures 4 and 5). The fresh waters had a carbonate/chloride and sodic/potassic chemical profile, whereas the most mineralized waters had a carbonate and sodic type. The $\mathrm{pH}$ values ranged from 7.05 to 9.91. Silica contents were particularly high in this alkaline environment, ranging from 0.18 to $4.35 \mathrm{mmol} \mathrm{L}^{-1}$, although some samples had a relatively low $\mathrm{SiO}_{2}$ content compared to the rest of the sampling.

The correlation matrix (Table 2) showed a close relationship between $\mathrm{Na}^{+}$and carbonate alkalinity. A moderately close relationship was observed between these variables $\left(\mathrm{Na}^{+}\right.$, carbonate alkalinity) and $\mathrm{Cl}^{-}, \mathrm{SO}_{4}{ }^{2-}$, and $\mathrm{K}^{+}$. The examination of the singular values (Table 3 ) revealed that the axis of the first factorial plan accounted for $58.12 \%$ and $20.5 \%$ of the variance of the data set. The first axis opposed concentrated waters of the salinas and associated piezometers to the fresh waters of the rivers, corixos and vazantes (Figures 6 a and c). The second axis opposed samples with high $\mathrm{Ca}^{2+}$ and $\mathrm{Mg}^{2+}$ contents to the rest of the sampling. The third axis opposed samples with relatively high $\mathrm{Ca}^{2+}$ and low $\mathrm{Mg}^{2+}$ to samples with low $\mathrm{Ca}^{2+}$ and high $\mathrm{Mg}^{2+}$ (Figure $6 \mathrm{~b}$ and $\mathrm{d}$ ).

Equilibrium diagrams indicate that the less mineralized solutions are under-saturated with respect to calcite, whereas most of the solutions are at equilibrium or slightly over-saturated with respect to that mineral (Figure 7a). The ten most concentrated solutions reached the equilibrium with respect to magnesite (Figure $7 b$ ). All the samples are under-saturated with respect to neutral salts like gypsum $\left(\mathrm{CaSO}_{4}, 2 \mathrm{H}_{2} \mathrm{O}\right.$; Figure $\left.7 \mathrm{c}\right)$ or halite $(\mathrm{NaCl}$; Figure $7 \mathrm{~d})$. The most concentrated solution remains under-saturated with respect to the sodium carbonates $\left(\mathrm{Na}_{2} \mathrm{CO}_{3} .10 \mathrm{H}_{2} \mathrm{O}\right.$; Figure $7 \mathrm{e} ; \mathrm{Na}_{2} \mathrm{CO}_{3} \cdot \mathrm{NaHCO}_{3} .2 \mathrm{H}_{2} \mathrm{O}$; Figure $\left.7 \mathrm{f}\right)$, although this salt was identified in the field around some salinas, for example "Salina das Pedras" in the Berenice farm. This confirms that the sodium molality is adequate to estimate a concentration factor. Even for the most dilute lagoas, solutions are well above the quartz solubility, and most samples are near the equilibrium with respect to amorphous silica. The equilibrium with respect to $\mathrm{Mg}$-silicate (stevensite, sepiolite...) is reached (Figure $7 \mathrm{~g}$ ).

On the concentration diagrams (Figure 8), the solid lines are unit slope lines, (i.e., a hypothetical evolution proportional to the sodium contents). The $\mathrm{pH}$ values and alkalinity increase with the mineralization of the solutions. In Figures $8 \mathrm{a}$ and $8 \mathrm{~b}$, the plots show a similar distribution, (i.e., $\mathrm{pH}$ and alkalinity increasing proportionally to the sodium molalities from $\left(\mathrm{Na}^{+}\right)=0.07$ to $1.5 \mathrm{meq} \mathrm{L}^{-1}$ and less steadily for higher sodium molalities). The chloride molalities also increase along the concentration gradient (Figure 8c). However, the plot shows a decrease for sodium molalities close to $5.2 \mathrm{meq} \mathrm{L}^{-1}$. After this value, the chloride contents increase again and more steadily than the sodium molalities, but the 1:1 line, drawn from the most diluted solutions, is not reached, even for the most concentrated solutions. The sulfate plot (Figure 8d) is more scattered but shows a similar behavior to that of chloride. The calcium and magnesium contents increase until sodium molalities are close to 1.5 meq $\mathrm{L}^{-1}$ (Figures 8e and 8f), and they then level off, while the scatter of the data increases. Potassium 
and phosphate concentrations increase as waters become more saline (Figures $8 \mathrm{~g}$ and $8 \mathrm{~h}$ ), with a slope close to 1:1 (i.e., proportionally to the sodium molalities). However, some points clearly depart from the rest of the sampling, having lower values. For these samples, similar behavior is noted on the scatter plots of potassium and phosphate, but also magnesium and possibly sulfate. Total silica contents are close to $1 \mathrm{meq} \mathrm{L}^{-1}$ for sodium molalities, ranging from 0.07 to $7.5 \mathrm{meq} \mathrm{L}^{-1}$, and they then increase in the most mineralized samples (Figure 8i).

The simulation of evaporation of dilute water (dotted lines on Figure 8) agrees well with the evolution highlighted from the concentration diagrams of the observed data. With respect to the elements that are little or not controlled, a good agreement with the evolution of alkalinity, $\mathrm{pH}$, potassium, and silica is noted. In spite of a more scattered plot, the simulation agrees with the significant control of $\mathrm{Ca}$ and $\mathrm{Mg}$. However, the simulation is not in agreement with the evolution of the chloride and sulfate ions.

\section{DISCUSSION}

The first axis of the Principal Component Analysis indicates the global concentration of the solutions. Therefore, concentration of dissolved elements, mainly due to evaporation, seems to be the principal process responsible for the chemical variability in the Nhecolândia. All the samples seem to belong to the same geochemical family. The close relationship between carbonate alkalinity and the elements that are generally used as concentration tracer $\left(\mathrm{Na}^{+}, \mathrm{Cl}^{-}\right)$ indicates that the carbonate alkalinity is not strongly affected by control processes when the waters concentrate, evolving in an alkaline manner.

The second variability factor in the chemical data set is the control of $\mathrm{Ca}^{2+}$ and $\mathrm{Mg}^{2+}$, which are not correlated with the solutes not or weakly controlled, like $\mathrm{Na}^{+}$and carbonate alkalinity. $\mathrm{Ca}^{2+}$ is most likely controlled by calcite precipitation along the concentration gradient. In the fresher waters, carbonate alkalinity is higher than the amount of calcium, as illustrated by the Schoeller diagram (Figure 5). Calcite residual alkalinity is positive. Thus, when the solutions concentrate and calcite precipitates, calcium concentration decreases and the carbonate alkalinity increases, although less rapidly than sodium molalities, because a part of the alkalinity is taken up from solution by calcite formation. This evolution is consistent with the law of calcite residual alkalinity.

The third axis of the PCA is more difficult to interpret because $78.6 \%$ of the variance is already explained with the first factorial plan (Table 3). The difference observed for $\mathrm{Mg}$ between the data and the simulation could be explained if calcite was a magnesian variety, thus simultaneously controlling $\mathrm{Ca}^{2+}$ and $\mathrm{Mg}^{2+}$ molalities. However, the concomitant uptake of $\mathrm{Ca}^{2+}$ and $\mathrm{Mg}^{2+}$ and the precipitation of $\mathrm{Mg}$-calcite cannot be the sole geochemical process responsible for the control of $\mathrm{Mg}^{2+}$ molalities. The third axis of the PCA, opposing $\mathrm{Ca}^{2+}$ and $\mathrm{Mg}^{2+}$, suggests another mechanism independent of the control of $\mathrm{Ca}^{2+}$. The saturation with respect to magnesite is reached only by some solutions. Therefore, the contribution of this mineral to $\mathrm{Mg}^{2+}$ control is unlikely. Rather, magnesium molalities could be controlled by formation of a magnesian silicate (e.g., stevensite, sepiolite, Mg-montmorillonite, or amorphous Mg-silicates), which is frequent in alkaline environments (Garrels and Mackenzie 1967, Gac et al. 1977 a and b, Jones et al. 1977, Jones and Galand 1988, Valles et al. 1989). The equilibrium diagram (Figure $7 \mathrm{~g}$ ) indicates that formation of magnesian silicates is indeed possible. $\mathrm{Mg}$ initially could be buffered by formation of $\mathrm{Mg}$-calcite and subsequently by precipitation of a Mg-Silicate. The high silica contents observed in the most concentrated waters $(\mathrm{pH}>9)$ can be attributed to the dissociation of orthosilicic acid $\left(\mathrm{Si}(\mathrm{OH})_{4}\right)$ into $\mathrm{SiO}(\mathrm{OH})_{3}{ }^{-}$as indicated by the simulation.

In short, the evaporative concentration and the associated geochemical processes (calcite or Mg-calcite precipitation, Mg-silicate formation) may well be responsible for about $92 \%$ of 
the variance in the sampling (PC axis 1, 2, and 3).

The evolution of the potassium contents along the concentration gradient suggests that exchange processes in the soil are insignificant, which was expected because of the sandy soil texture. High-Na solutions that are low in potassium, phosphates, magnesium, and sulfate contents were sampled in various salinas distant from each other. It is therefore likely that a regional-scale process controls these elements. It affects the free water of the salina without affecting the solution in the neighboring water table. It is probably related to the algal bloom frequently observed in the salinas of the Nhecolândia.

The geochemical processes previously described cannot explain the decrease in sulfate and chloride amounts in waters with intermediate ionic strengths. Clearly, processes involving large sulfate and chloride losses are at work here. Similar sulfate variations have been observed in the alkaline Magadi basin in Africa (Jones et al. 1977). The two processes evoked are reduction and sorption. Although we found no evidence for sulfate reduction during prospecting in the field, it is a likely process in this environment. A comparison of the chloride and sulfate versus sodium plots (Figures $8 \mathrm{c}$ and d) suggests that $\mathrm{Cl}^{-}$and $\mathrm{SO}_{4}{ }^{2-}$ have been involved in a same process. It is becoming increasingly accepted that Fe solutionmineral equilibrium is often controlled by a labile "ferroso-ferric hydroxide" (Ponnamperuma 1967, Ponnamperuma et al. 1972) or green rusts (Trolard et al. 1997). Among the compensating interlayer anions, $\mathrm{OH}^{-}$can be partially substituted for $\mathrm{Cl}^{-}, \mathrm{SO}_{4}{ }^{2-}$, or $\mathrm{CO}_{3}{ }^{2-}$ (Bourrié et al. 1999). The low $\mathrm{Cl}^{-}$and $\mathrm{SO}_{4}{ }^{2-}$ concentration in waters of intermediate ionic strength could also be attributed to substitutions in such reduced minerals, particularly in the green horizons frequently observed at about 1 to $4 \mathrm{~m}$ depth in the mountain range areas (Fernandes et al. 1999). The reversibility of the precipitation/dissolution reaction of green rusts, in agreement with their well-known lability, could explain that a proportion of lost $\mathrm{SO}_{4}{ }^{2-}$ and $\mathrm{Cl}^{-}$are released near the temporary oxidized salinas. Specific studies based on the sampling of free soil solution and its conservation in anoxic conditions are currently in progress to verify this hypothesis.

The chemical evolution of the waters in this part of the Pantanal wetland is in its broad outline, similar to that observed in some areas of continental Africa, North America, or Europe, although the climatic conditions and the sedimentary framework are clearly different. For example, the Tisza valley in Hungary, the lower Danube plain in Romania, the Nebraska Sand Hills in North America, and the Chad Lake or salty lakes along the oriental rift in Ethiopia or Kenya show similar chemical composition and processes as water becomes concentrated due to evaporation (Gac et al. 1977, Jones et al. 1977, Droubi et al. 1980). Waters originating from old cratons generally have a carbonate-dominating chemical composition and evolve in a sodic alkaline manner under the influence of evaporation. Therefore, this similarity with the African craton is probably due to the geological characteristics of the high Paraguay basin, whereby the Nhecolândia is supplied by waters from the old Brazilian craton.

\section{CONCLUSIONS AND PERSPECTIVES}

The presence of saline lakes (Salinas) is a peculiarity of the Nhecolândia, a subregion of the Pantanal wetland. Until now, the salt has always been attributed to alternating humid and arid phases during Pleistocene (i.e., inherited from the past). The geochemical analyses presented in this paper indicates a unique geochemical family of waters evolving currently in an alkaline manner under the influence of evaporation. The geochemical composition changes gradually from weakly mineralized waters that flood the region during the rain season to the strongly mineralized ones in the salinas. The processes responsible for most of the changes in 
the chemical characteristics of the water are the precipitation of calcite or $\mathrm{Mg}$-calcite and probably the formation of $\mathrm{Mg}$-silicates as waters become more saline.

Although evaporation can account for most of the chemical variability in the region, the geographical distribution of a number of landscape distinctive features seems to interfere with this scenario. In particular, sulfate and chloride values show the most significant deviation from an evaporation-controlled concentration pattern. This may be due to the fact that labile iron minerals cause extensive substitution in the green horizons in the cordilheira areas. However, this hypothesis needs to be verified by specific sampling of soil and soil solution preserved from contact with the atmosphere.

The next research efforts should focus on the water and solute flows in the landscape to explain how wetlands subjected to the same amount of evaporation can have such different chemical characteristics. Our study has indeed shown that the range of water mineralization detected in this regional sampling from fresh to saline water (approximately 4500 times) cannot result from a yearly accumulation but must arise from several decades of functioning of this ecosystem. It follows that any modification of the environment that could lead to the possible desalinization of a salina would cause an irreversible damage. The salinas are an essential component of the principal economical activity of this region (i.e., cattle breeding). Being located in the extreme lowlands, these salinas provide water even during the driest periods, as well as valuable mineral complements for cattle, which feed primarily on poorquality local grass (Comastri and Pott 1998). The salinas must, therefore, be regarded as a fragile resource requiring sustainable management.

\section{ACKNOWLEDGMENTS}

This work has been financed by the FAPESP 97/11799-5 (Fundação de Amparo a Pesquisa do Estado de São Paulo). The authors are very grateful for the field assistance provided by EMBRAPA-Pantanal.

\section{LITERATURE CITED}

Ab'Saber, A. N. 1988. O Pantanal Mato Grossense e a teoria dos refugios. Revista Brasileira de Geografia 50 special 1-2:9-57.

Alho, C. J. R., T. E. Lacher, and H. C. Gonçalves. 1988. Environmental degradation in the Pantanal ecosysthem. Bioscience 38:164-171.

Almeida, F. F. M. and M. A. Lima. 1956. Excursion Guidebook 1. 18th International Geography Congress, Rio de Janeiro, Brazil.

Brum, P. A. R. and J. C. Souza. 1985. Níveis de nutrientes minerais para gado, em lagoas no Pantanal Sul Mato-Grossense. Pesquisa Agropecuária Brasileira 20:1451-1454.

Cunha, J. 1943. Análise química das águas. Cobre do Jauru : lagoas alcalinas do Pantanal. 
Boletim do Laboratório de Produção Mineira 6:18-19.

Charlot, G. 1961. Dosage Colorimétrique des Eléments Minéraux. Principes et Méthodes. Deuxième édition, Masson, Paris, France.

Bourrié, G., F. Trolard, J. M. R. Génin, A. Jaffrezic, V. Maître, and M. Abdelmoula. 1999. Iron control by equilibria between hydroxy-Green Rusts and solutions in Hydromorphic soils. Geochimica et Cosmochimica Acta 63:3417-3427

Colinvaux, P. A., P. E. Oliveira, and M. B. Bush. 2000. Amazonian and neotropical plant communities on glacial time-scales. The failure of the aridity and refuge hypotheses. Quaternary Science Reviews 19:141-169.

Comastri, J. A. and A. Pott. 1998. Forage species introduction and evaluation on semicleared ancient levees in the Nhecolandia subregion of the Brazilian Pantanal. Pesquisa Agropecuaria Brasileira 33:793-802.

Da Silva, J. D. and M. D. Abdon. 1998. Delimitation of the Brazilian Pantanal and its subregions. Pesquisa Agropecuaria Brasileira 33:1703-1711.

Droubi, A. Al, B. Fritz, J. Y. Gac, and Y. Tardy. 1980. Generalized residual alkalinity concept; Application to prediction of the chemical evolution of natural waters by evaporation. American Journal of Science 280:560-572.

Eaton, F. M. 1950. Signifiance of carbonates in irrigation waters. Soil Science 69:123-133.

Eiten, G. 1983. Classificação da vegetação do Brasil. CNPq/Coordonação editorial, Brasilia, Brazil.

Fassel, V. A. 1978. Quantitative elemental analysis by plasma emission spectroscopy. Science 202:183.

Fernandes, E., A. Y. Sakamoto, J. P. Queiroz Neto, H. M. Lucati, and B. Capellari. 1999. Le «Pantanal da Nhecolândia » Mato Grosso. Cadre physique et dynamique hydrologique. Geografia Física e Dinâmica Quaternária 22:13-21.

Gac, J. Y., A. Al Droubi, B. Fritz, and Y. Tardy. 1977a. Geochemical behaviour of silica and 
magnesium during the evaporation of waters in Chad. Chemical Geology 19:215-228.

Gac, J. Y., D. Badaut, A. Al Droubi, and Y. Tardy. 1977b. Comportement du calcium, du magnesium et de la silice en solution. Précipitation de calcite magnésienne, de silice amorphe et de silicates magnésiens au cours de l'évaporation des eaux du Chari (Tchad). Sciences Géologiques Bulletin 31:185-193.

Garrels, R. M. and F. T. Mackenzie. 1967. Origin of the chemical composition of some springs and lakes, in Gould R.F. ed., Equilibrium concepts in natural water Systems. Advances in Chemistry Series 67:222-242.

Gottgens, J. F., R. H. Fortney, J. Meyer, J. E. Perry, and B. E. Rood. 1998. The case of the Paraguay-Paraná waterway ("Hidrovia") and its impact on the Pantanal of Brazil: a summary report to the Society of Wetlands Scientists. Wetlands Bulletin:12-18.

Gran, G. 1952. Determination of the equivalence point in potentiometric titrations. Acta Chemica Scandinavica 4:559-577.

Hamilton, S. K., O. Corrêa de Souza, and M. E. Coutinho. 1998. Dynamic of floodplain inondation in the alluvial fan of the Taquari River (Pantanal, Brazil). Verhandlungen der Internationale Vereinigung für theoretische und angewandte Limnologie 26:916-922.

Hamilton, S. K. 1999. Potential effects of a major navigation project (Paraguay-Parana hidrovia) on inundation in the Pantanal floodplains. Regulated Rivers: Research \& Management 15:289-299.

Hardie, L. A. and H. P. Eugster. 1970. The evolution of close basin brines. Mineralogical Society of America Special Paper 3:273-290.

IBGE. 1989. Geography of Brazil. V. 1. IBGE Found. Rio de Janeiro, Brazil.

Jones, B. F., H. P. Eugster, and S. L. Rettig. 1977. Hydrochemistry of the lake Magadi basin, Kenya. Geochimica et Cosmochimica Acta 41:53-72.

Jones, B. F. and E. Galan. 1988. Palygorskite-sépiolite. An Hydrous phyllosilicates exclusive of Micas. Geological Society of America Reviews in Mineralogy 19:631-674. 
Keller, C., G. Bourrié, and J. C. Védy. 1987. Formes de l'alcalinité dans les eaux gravitaires. Influence des métaux lourds contenus dans des composts. Sciences du Sol 25:17-29.

Klammer, G. 1982. Die Palaeowuste des Pantanal von Mato Grosso und die pleistozane Klimageschichte des brasilianischen Randtropen. Zeitschrift für Geomorphologie 26:393416.

Morrison, R. I. G., M. Manore, R. K. Ross, and C. R. Padovani. 2000. Identificação das lagoas salinas da região da Nhecolândia - Pantanal, através de técnicas de sensoriamento remoto - III Simpósio sobre Recursos Naturais e Sócio-econômicos do Pantanal, CorumbáMS, (Resumo):88-89.

Mourão, G. M. de, T. H. Ishii, and Z. M. S. Campos. 1988. Alguns factores limnológicos relacionados com a íchtiofauna de baías e salinas do pantanal da Nhecolândia, Mato Grosso do sul, Brasil. Acta Limnologica Brasiliensia 2:181-198.

Ponnamperuma, F. N. 1967. The chemistry of submerged soils. Advance in Agronomy 24:173-189.

Ponnamperuma, F. N., E. M. Tianco, and T. Loy. 1972. Redox equilibria in flooded soils I. The iron hydroxyde systems. Soil Science 103:374-381.

Por, F. D. 1995. The Pantanal of Mato Grosso (Brazil). World's Largest Wetlands. Kluwer Academic Publisher, Monographiae Biologicae 73, Dordrecht/Boston/London.

Queiroz Neto, J. P., A. Y. Sakamoto, H. M. Lucati, and E. Fernandes. 1999. Dinâmica hídrica de uma lagoa salina e seu entorno na área do Leque, Nhecolândia, Pantanal - MS. II Simpósio sobre Recursos Naturais e Sócio-econômicos do Pantanal. Corumbá, 18 a 22 novembro de $1996: 144-149$.

Sakamoto, A. Y. 1997. Dinâmica hídrica em uma lagoa salina e seu entorno no Pantanal da Nhecolândia: contribuição ao estudo das relações entre o meio físico e a ocupação, Fazenda São Miguel do Firme, MS. Ph.D. Thesis. University Sao Paulo, Sao Paulo, Brazil. Sakamoto, A. Y., J. P. Queiroz Neto, E. Fernandes, H. M. Lucati, and B. Capellari. 1999. 
Topografia de lagoas salinas e seus entornos no Pantanal de Nhecolândia. II Simpósio sobre Recursos Naturais e Sócio-econômicos do Pantanal. Corumbá, 18 a 22 novembro de $1996: 127-135$.

Scatchard, G. 1936. Concentrated solutions of strong electrolytes, Chemical Research 19: 309.

Stumm, W. and J. J. Morgan. 1970. Aquatic Chemistry. An Introduction Emphasing Chemical Equilibria in Natural Waters. Wiley Interscience, New York, NY, USA.

Tricart, J. 1982. El Pantanal : Un ejemplo del impacto de la Geomorphologia sobre el medio ambiente. Geografia 7:37-50.

Trolard, F., J. M. R. Génin, M. Abdelmoula, G. Bourrié, B. Humbert, and A. Herbillon. 1997. Identification of a Green Rust mineral in a reductomorphic soil by Mössbauer and Raman spectroscopies. Geochimica et Cosmochimica Acta 61:1107-1111.

Vallès, V. and F. Bourgeat. 1988. Geochemical determination of the gypsum requirement of cultivated sodic soils. I. Development of the thermodynamic model «gypsol» simulating the irrigation water-soil chemical interactions. Arid Soil Research and Rehabilitation 2:165-177.

Vallès, V., M. K. N’Diaye, A. Bernadac, and Y. Tardy. 1989. Geochemistry of water in the Kouroumari region, Mali. $\mathrm{Al}, \mathrm{Si}$ and $\mathrm{Mg}$ in water concentrated by evaporation: development of a model. Arid Soil Research and Rehabilitation 3:21-39.

Vallès, V. and A. M. De Cockeborne. 1992. Elaboration d'un logiciel de géochimie appliqué à l'étude de la qualité des eaux. Colloque "altération et restauration de la qualité des eaux continentales", Port Leucate, 1 et 2 Oct. $1992: 27-30$.

Van Beek, C. G. E. and N. van Breemen. 1973. The alkalinity of alkali soils. The Journal of Soil Science 24:129-136.

Vorob'yeva, A. and S. P. Zamana. 1984. The nature of soil alkalinity and methods of determining it. Pochvovedeniye 3:134-139. 
Wilhelmy, M. 1958. Das Grosse Pantanal. Die Weltumschau 18:555-559.

Figure 1. Location of the Pantanal wetland.

Figure 2. Location of the study site in the Nhecolândia, Mato Grosso do Sul state, Brazil. $\mathrm{X}$ : Sampling point.

Figure 3: Schematic distribution of the Nhecolândia landscape features.

1 : Salina; 2 : Cordilheira; 3 : Lagoa; 4 : Corixo; 5 : Vazante.

Figure 4. Piper diagram showing dissolved species distribution.

Figure 5. Schoeller diagram of three representative fresh (a) and concentrated (b) waters. 1 : Corixo; 2 : Negro River; 3 : Lagoa; 4 and 5 : Water table in cordilheira; $6:$ Salina.

Figure 6. Results of the Principal Component Analysis (PCA) calculations (a and b : visualization of the samples, 0 : Rivers, vazantes and corixos; $\mathrm{x}$ : Lagoas; + : Cordilheira's water table and Salinas; $\mathrm{c}$ and $\mathrm{d}$ : visualization of the chemical parameters).

Figure 7. Diagrams showing equilibrium conditions in solution for a) calcite, b) magnesite, c) gypsum, d) halite, e) natron, f) trona, g) magnesian silicates (o : Rivers, vazantes and corixos; x : Lagoas; + : Cordilheira's water table and Salinas). 
Figure 8. Concentration diagrams (solid line = unit slope line; dotted line = simulation, symbols as in Figure 7)

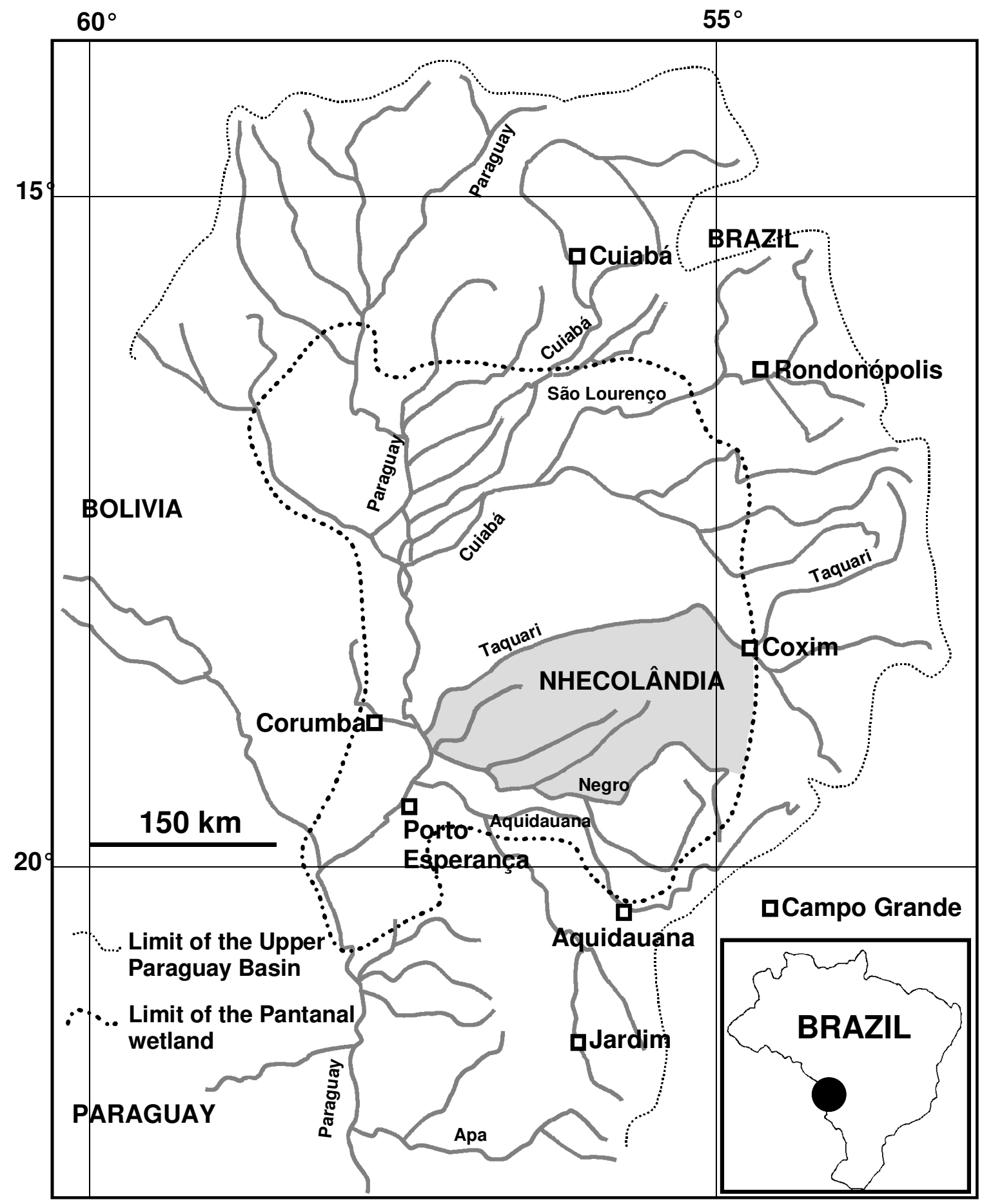




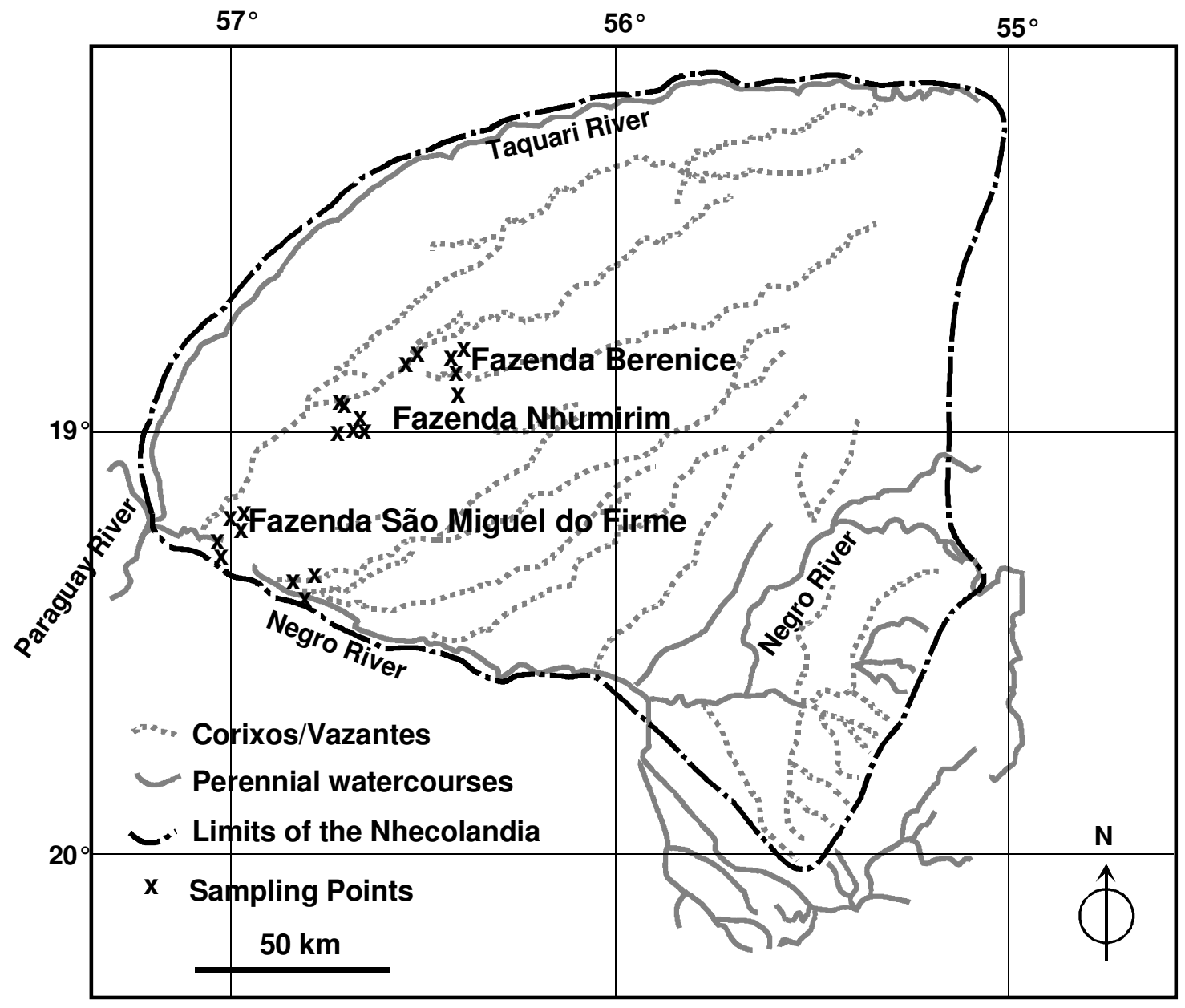



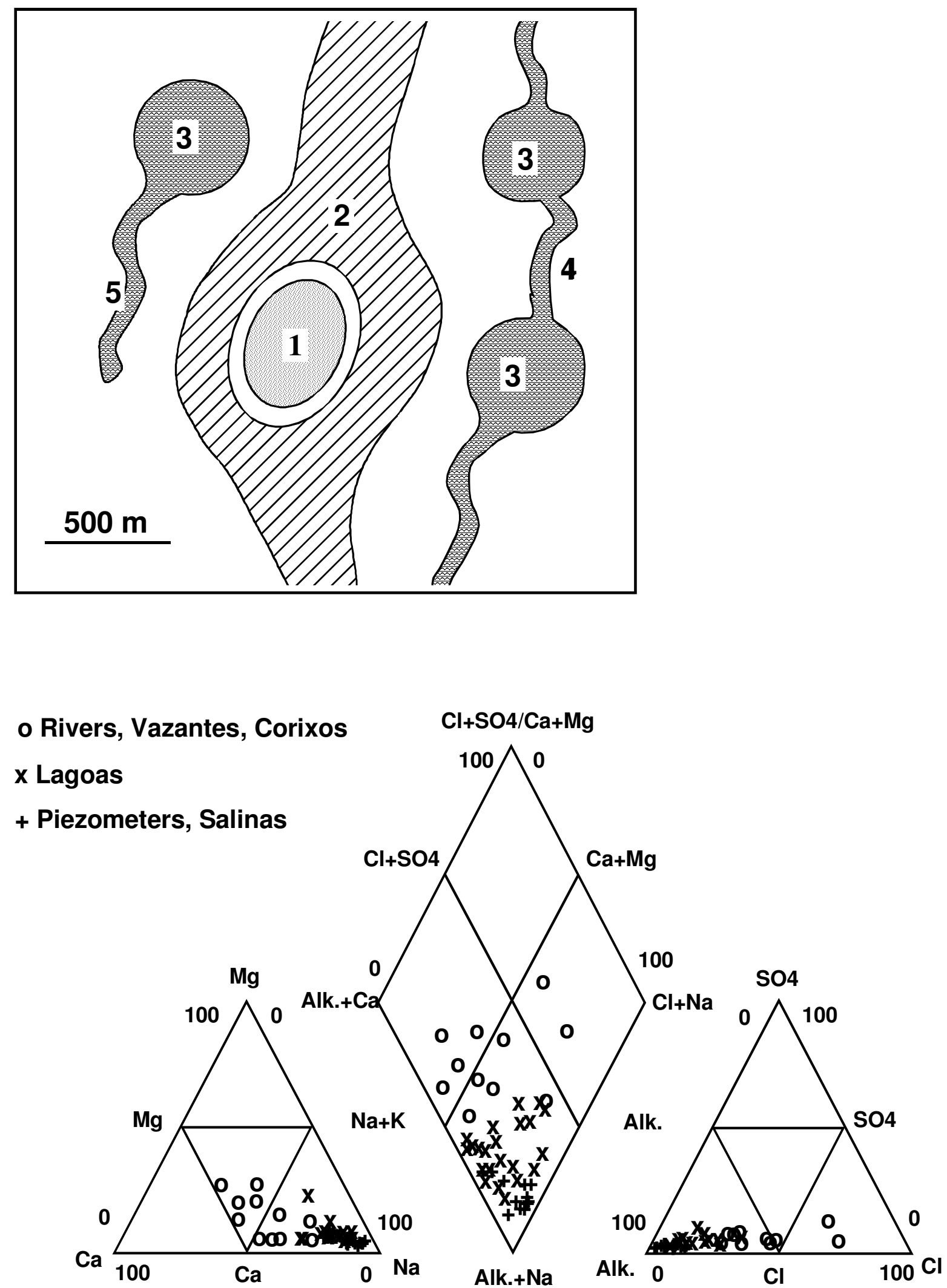


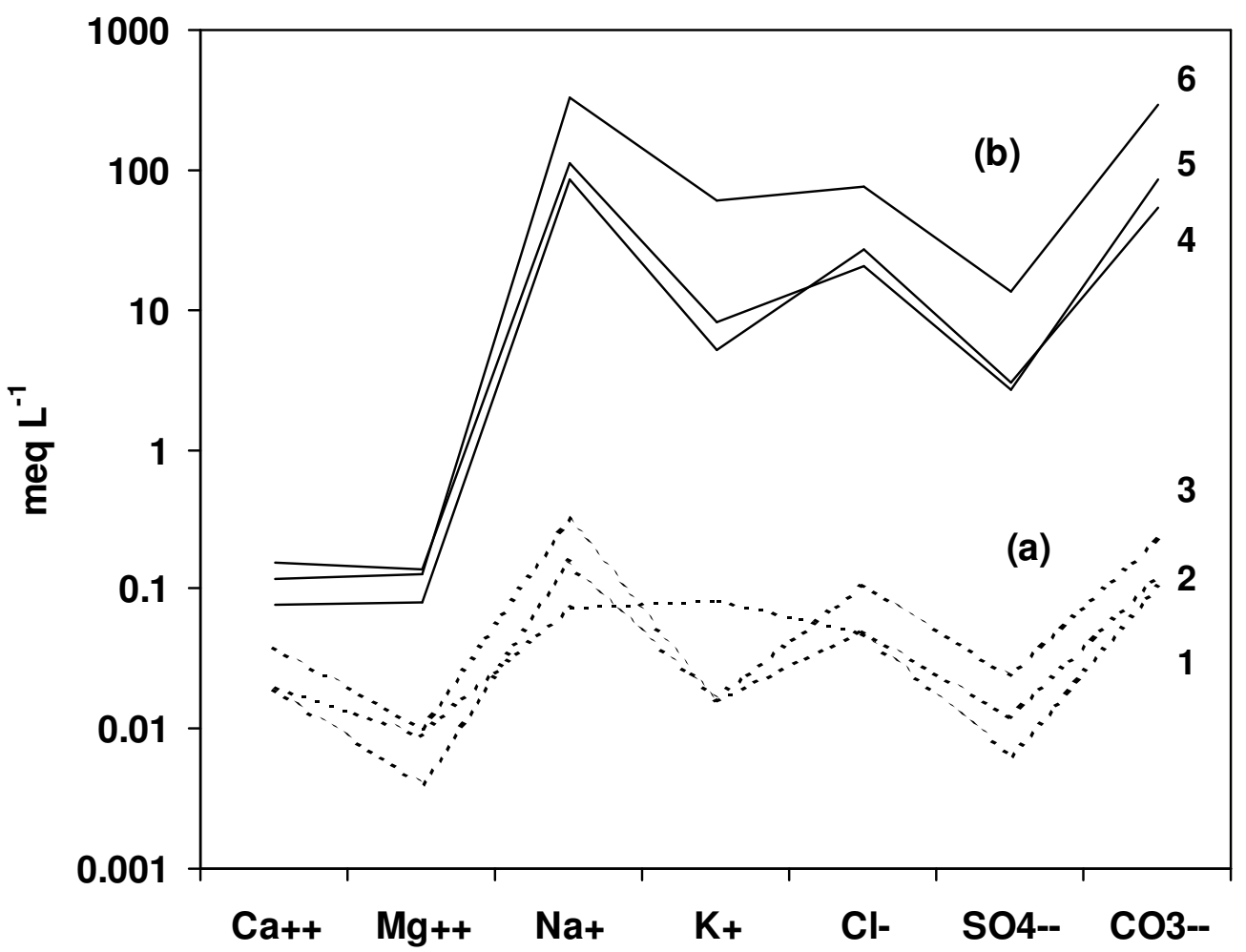


PCA Visualization of the samples

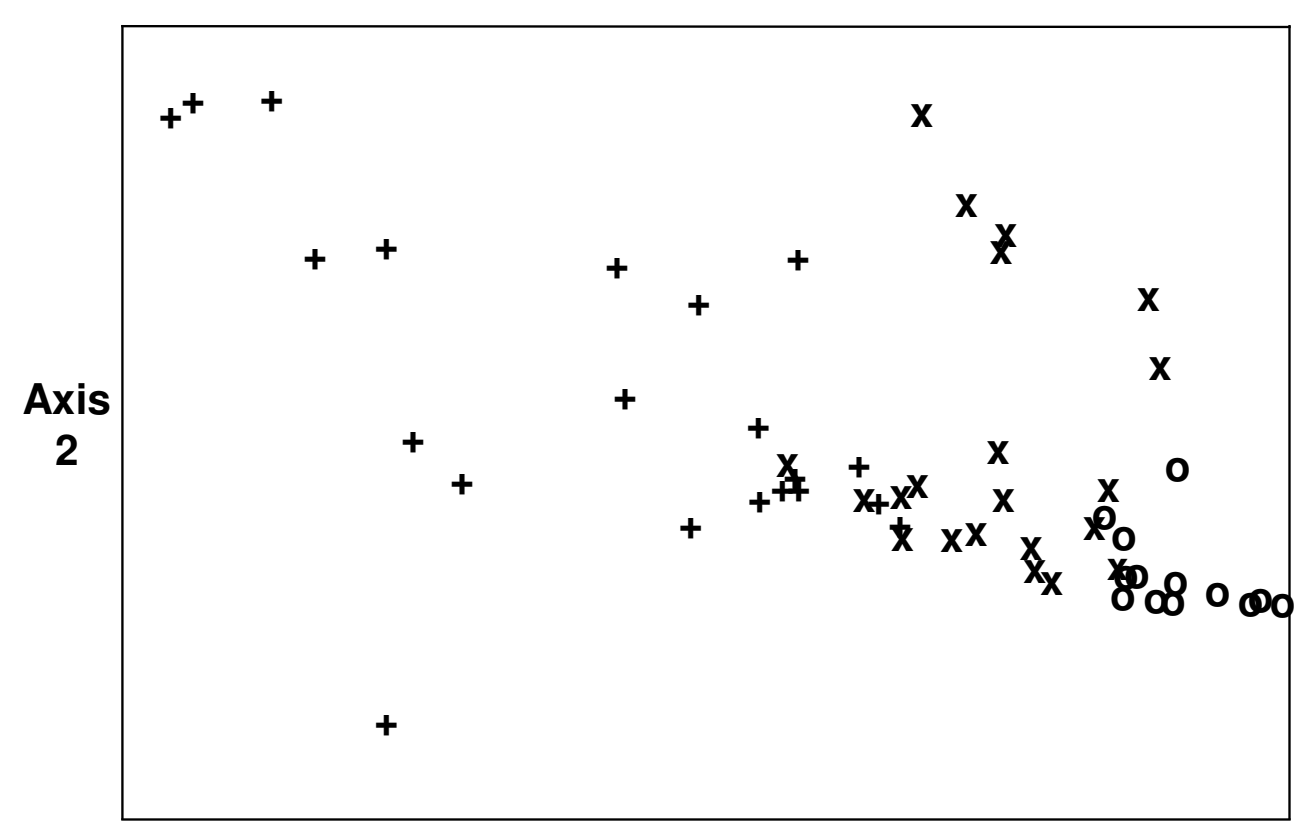

Axis 1

PCA Visualization of the Samples

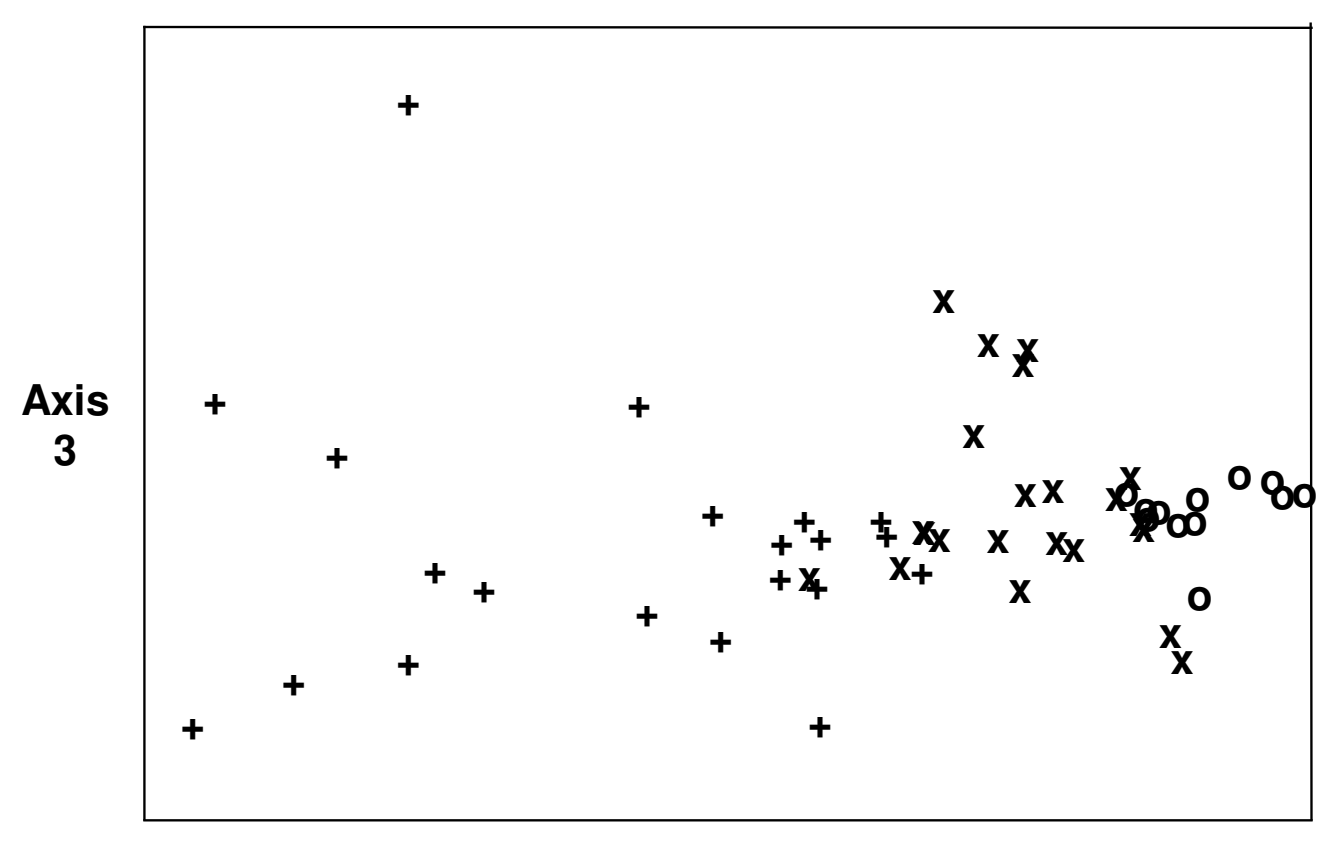

Axis 1 
PCA Visualization of the chemical parameters

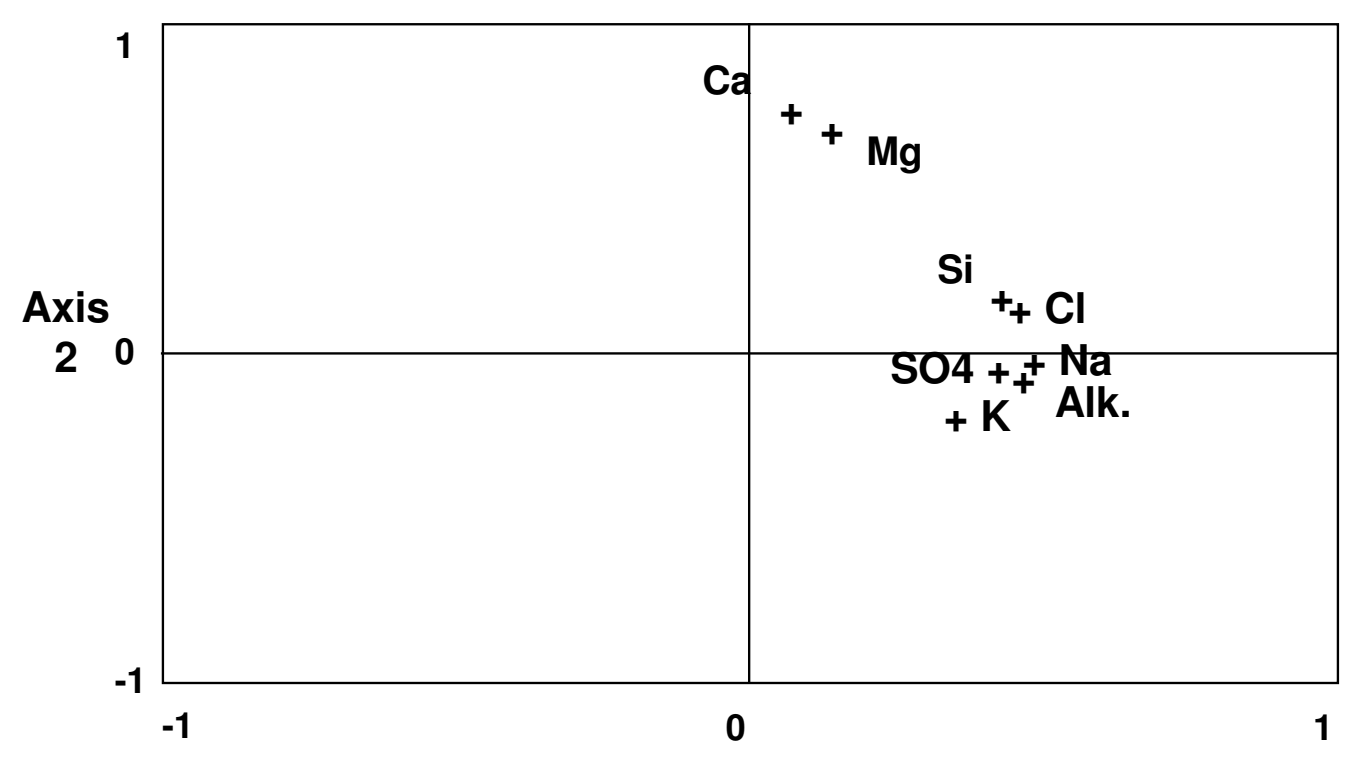

Axis 1

PCA Visualization of the chemical parameters

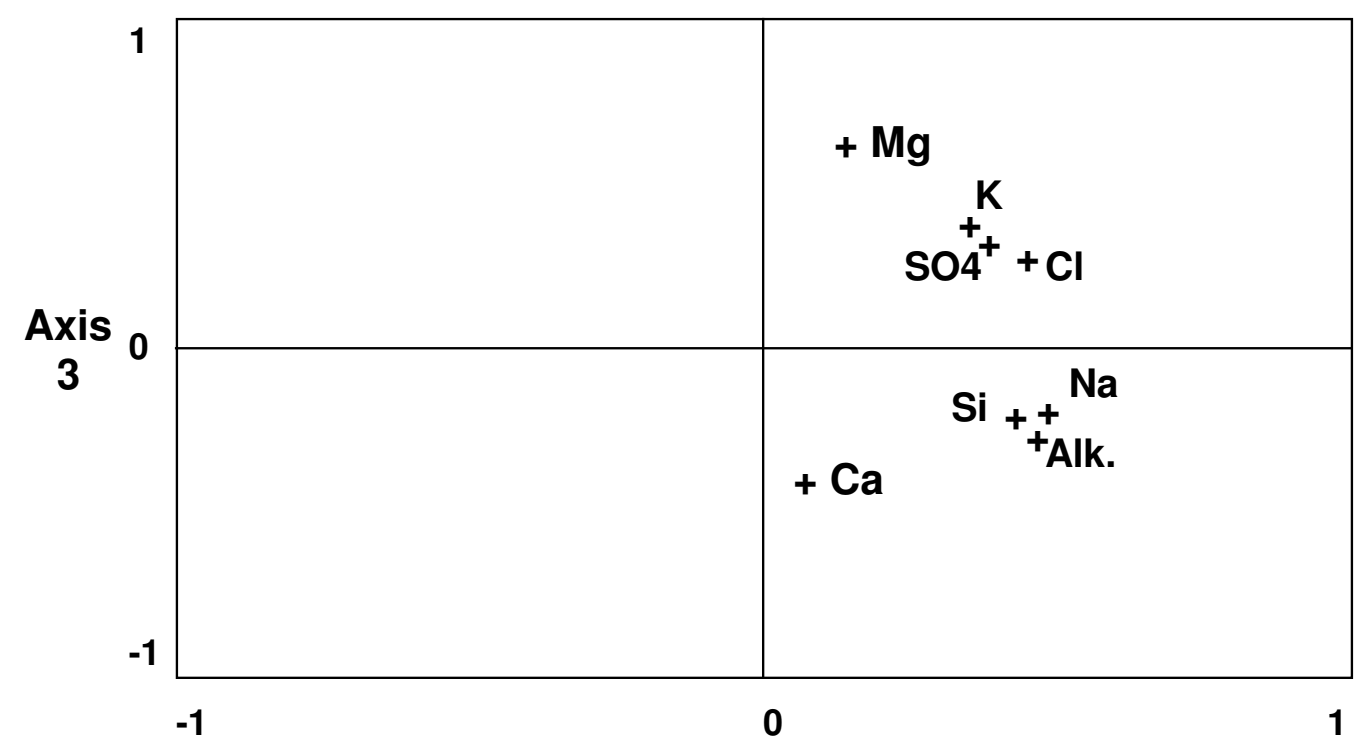

Axis 1 


\section{Calcite-solution equilibrium}

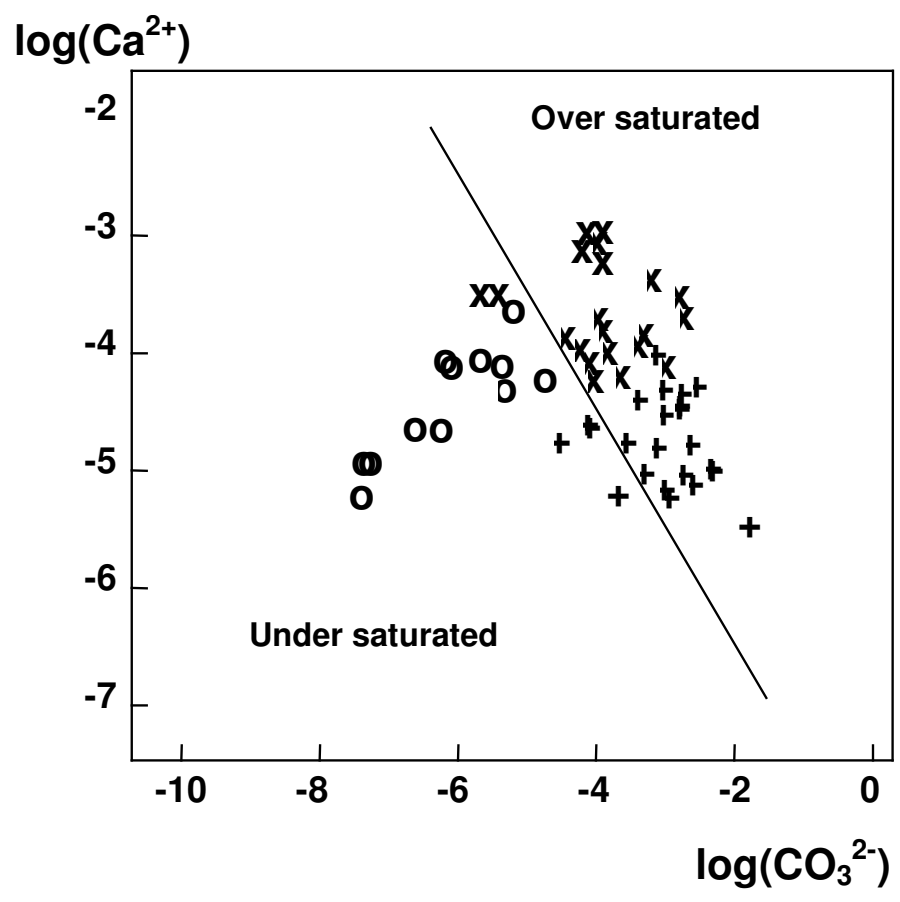

Magnesite-solution equilibrium

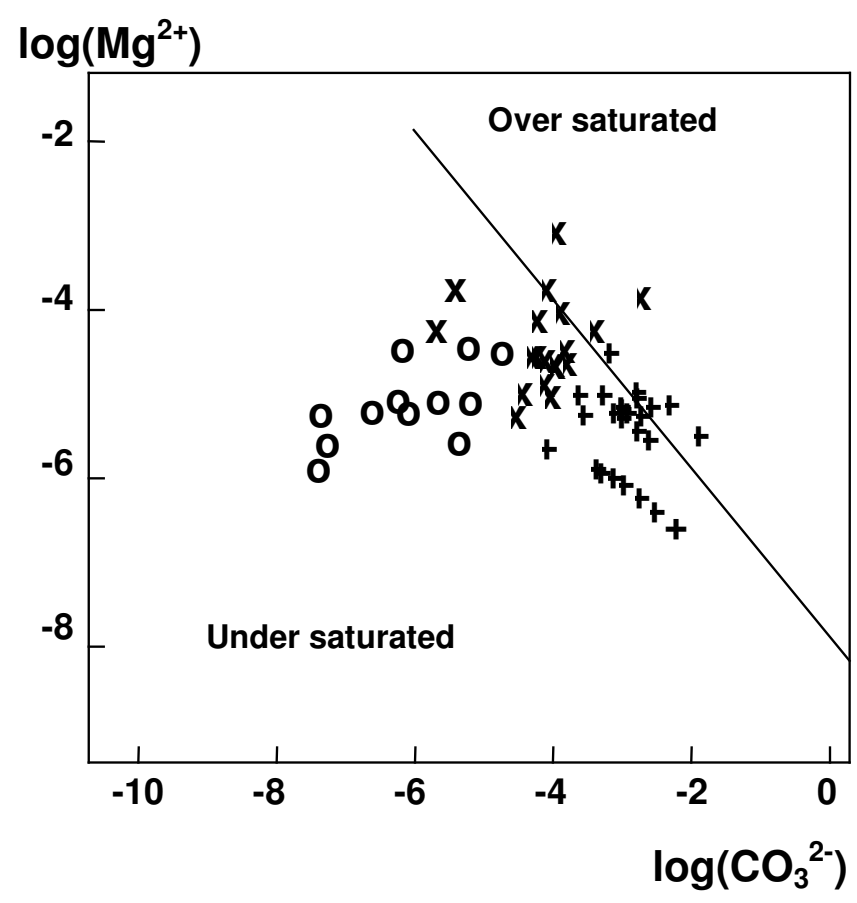




\section{Gypsum-solution equilibrium}

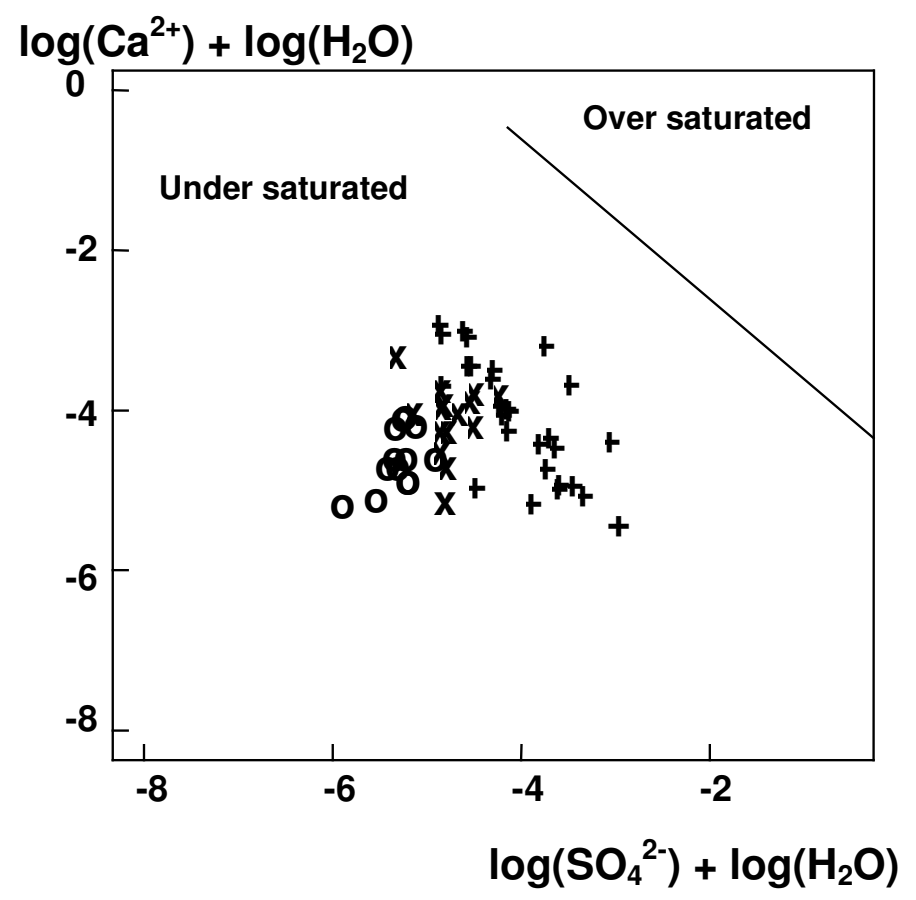

Halite-solution equilibrium

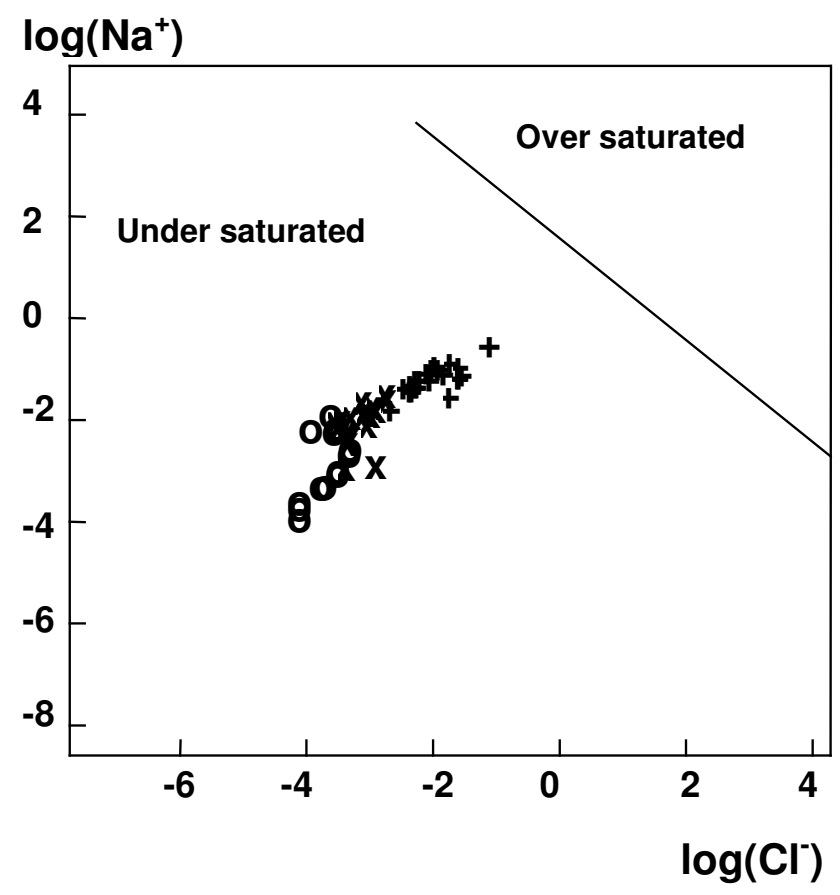




\section{Natron-solution equilibrium}

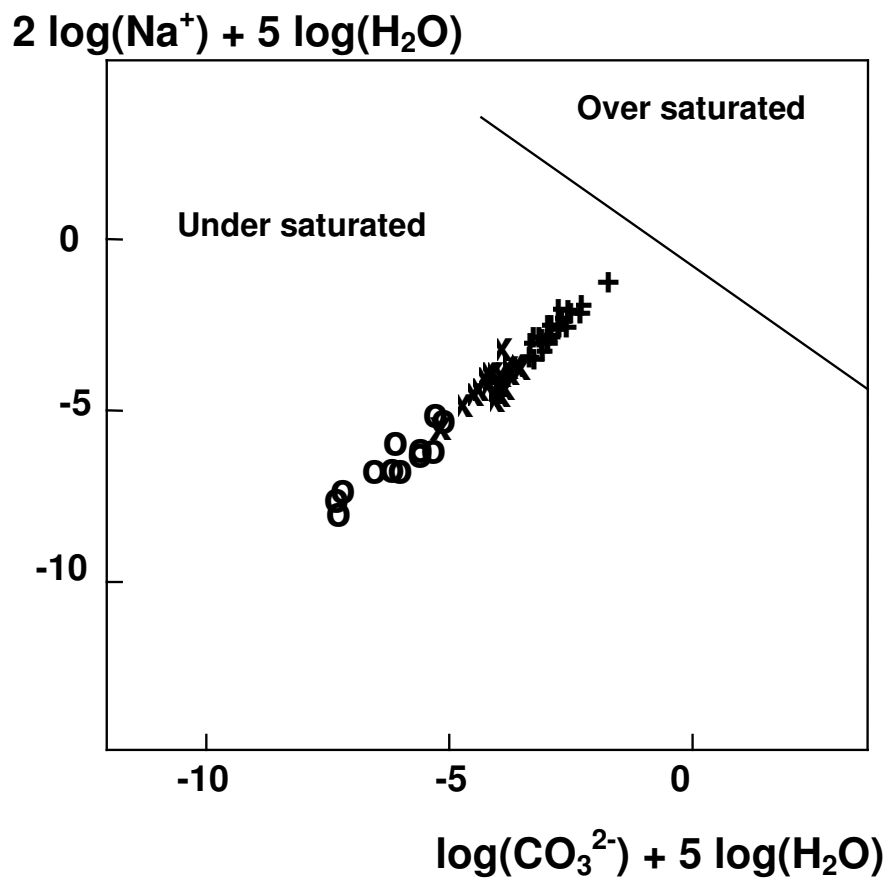


Trona-solution equilibrium

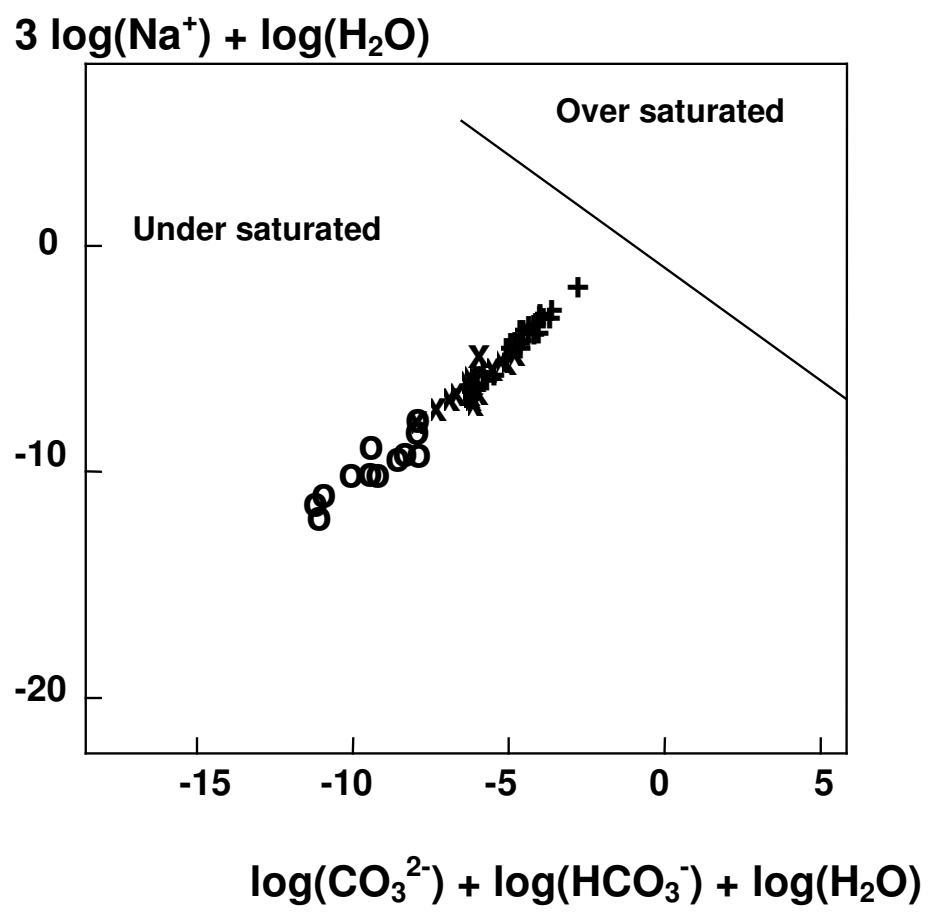

Magnesian silicate-solution equilibrium

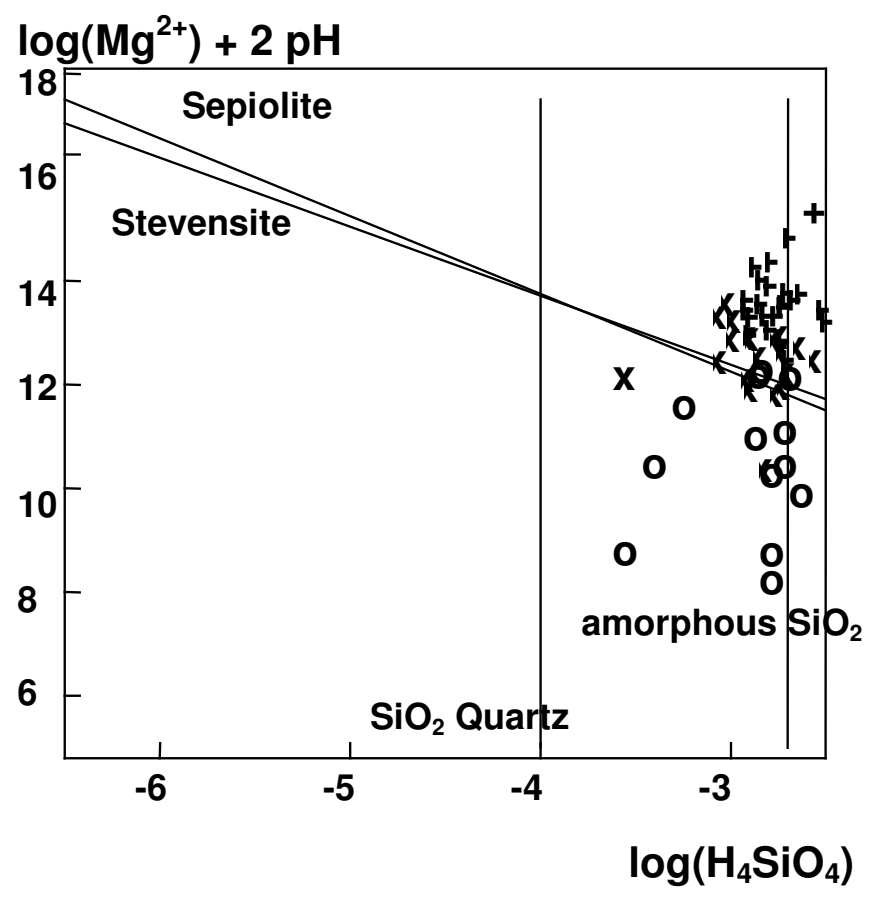



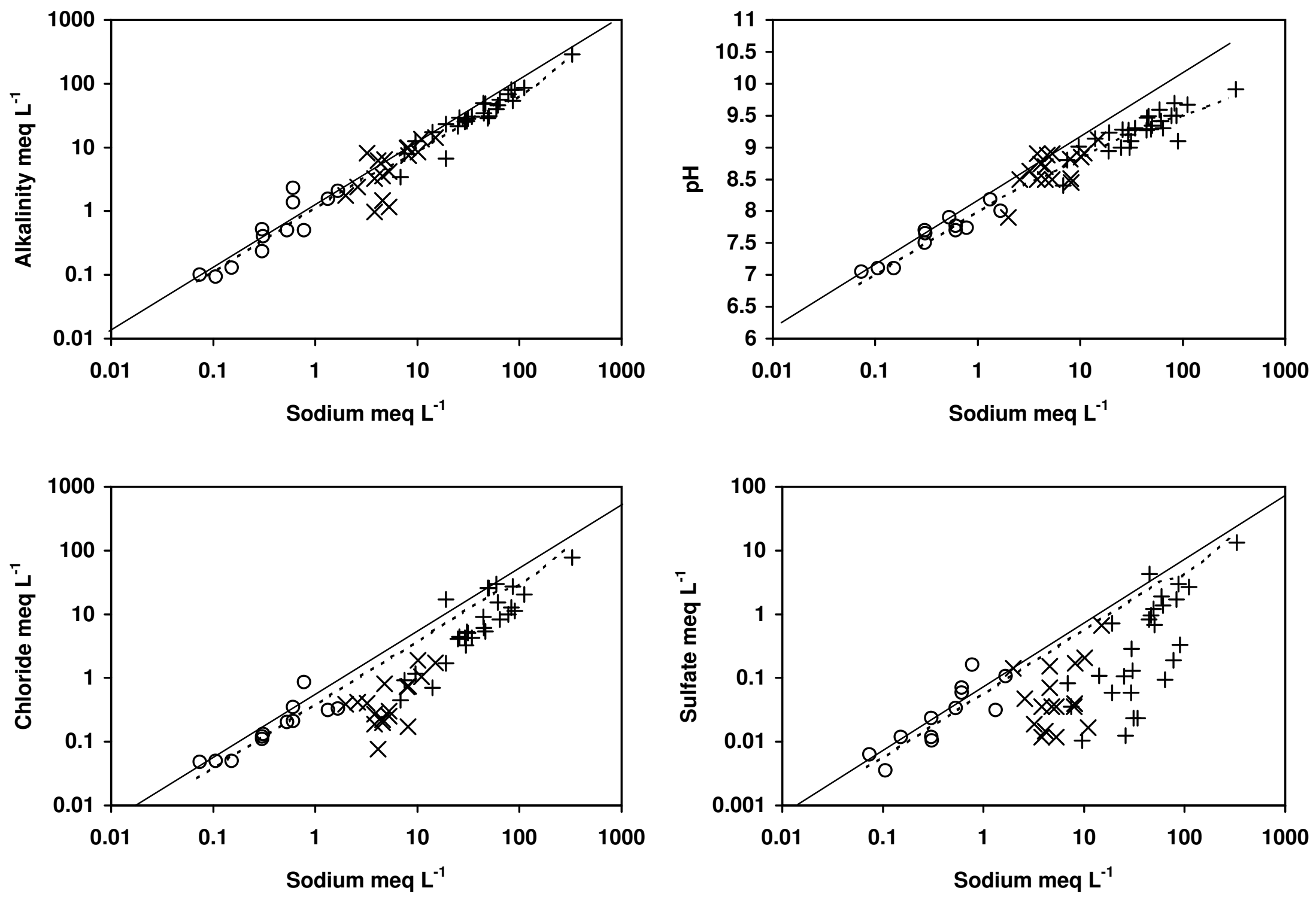

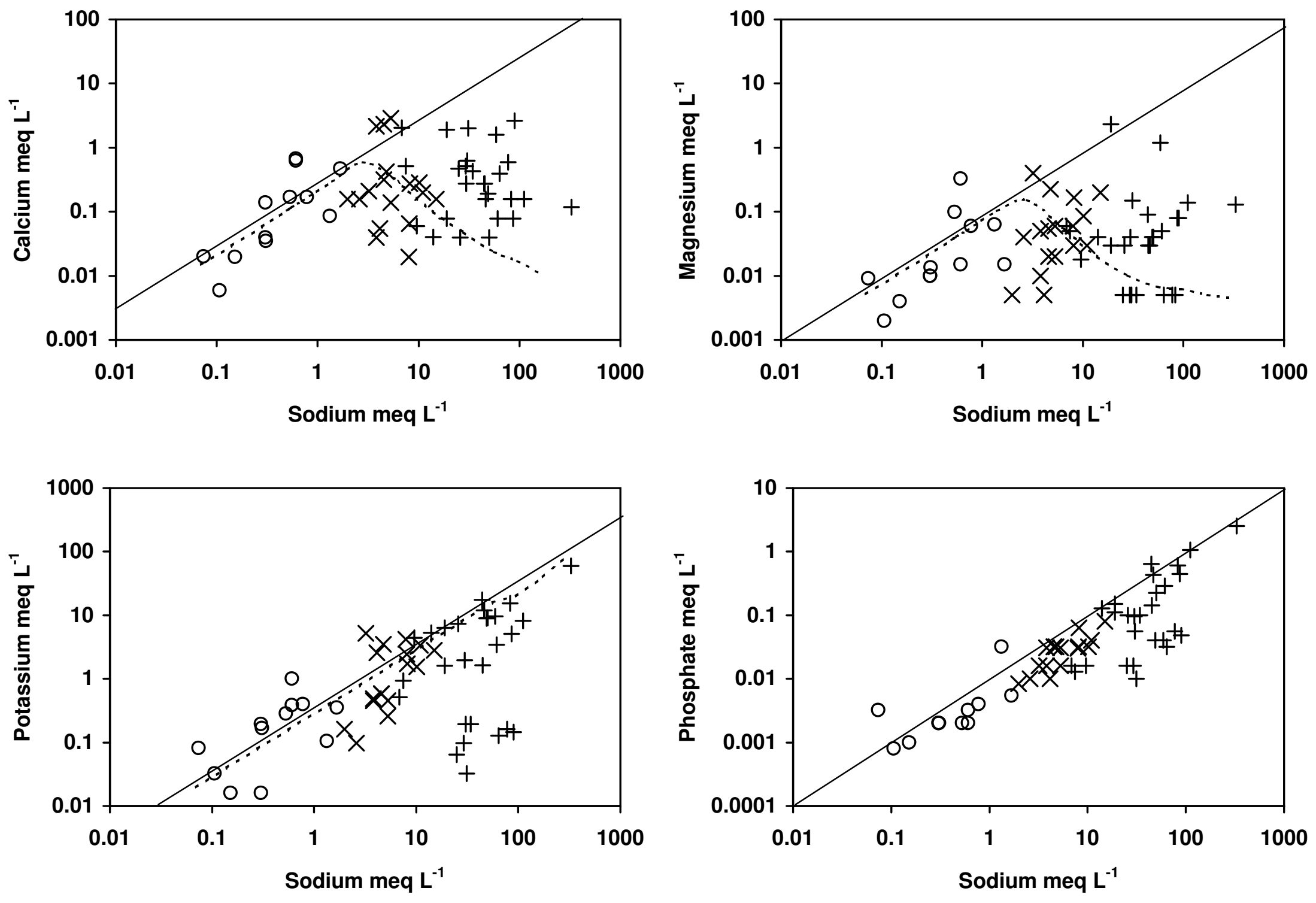

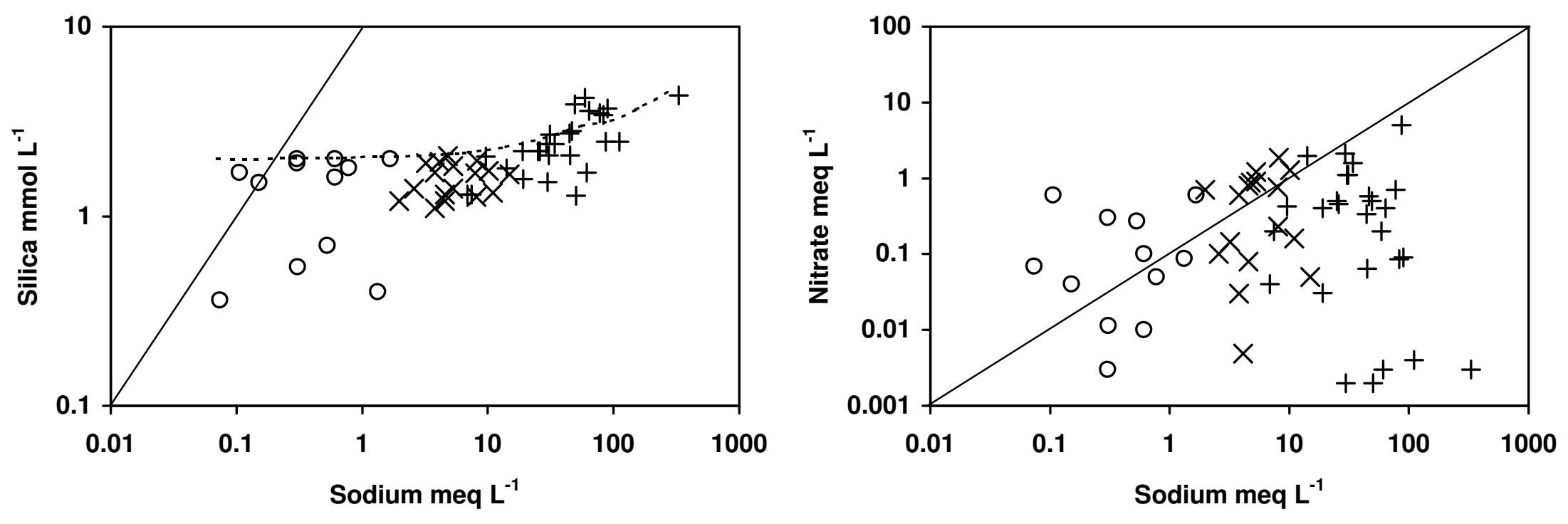